FAMILY DIVISIONS AND INEQUALITIES IN MODERN SOCIETY 
Also edited by Paul Close and published by Macmillan

FAMILY AND ECONOMY IN MODERN SOCIETY (with Rosemary Collins) 


\section{Family Divisions and Inequalities in Modern Society}

Edited by

Paul Close

Senior Lecturer in Sociology

Teesside Polytechnic 
(C) Paul Close 1989

Softcover reprint of the hardcover 1st edition 1989

All rights reserved. No reproduction, copy or transmission of this publication may be made without written permission.

No paragraph of this publication may be reproduced, copied or transmitted save with written permission or in accordance with the provisions of the Copyright Act 1956 (as amended), or under the terms of any licence permitting limited copying issued by the Copyright Licensing Agency, 33-4 Alfred Place, London WC1E 7DP.

Any person who does any unauthorised act in relation to this publication may be liable to criminal prosecution and civil claims for damages.

First published 1989

Published by

THE MACMILLAN PRESS LTD

Houndmills, Basingstoke, Hampshire RG21 2XS

and London

Companies and representatives

throughout the world

Typesetting by Footnote Graphics, Warminster, Wilts

ISBN 978-1-349-09339-7 ISBN 978-1-349-09337-3 (eBook)

DOI 10.1007/978-1-349-09337-3

British Library Cataloguing in Publication Data

Family divisions and inequalities in modern

society

1. Families-Sociological perspectives

I. Close, Paul, 1947-

$306.8^{\prime} 5$

ISBN 978-0-333-43657-8 
To Maud Mary and Linda Ann 


\section{Contents}

Lists of Figures and Tables

vii

Notes on the Contributors

Acknowledgements

ix

$\mathrm{xi}$

Introduction

Paul Close

1 Toward a Framework for the Analysis of Family Divisions and Inequalities in Modern Society

Paul Close

2 Persistence and Change in the Family and Gender in Australian Society

Michael Bittman and Lois Bryson

3 The Continuing Case of Japan Joy Hendry

4 The Significance of the Family and Marriage in the Federal Republic of Germany Rosemarie Nave-Herz

5 Myth and Reality in the Discovery and Representation of 92 Childhood

Giovanni Sgritta and Angelo Saporiti

6 Reproduction in Norway: an Area of Non-Responsibility? 112 An-Magritt Jensen

7 Illegitimacy, Inequality and the Law in England and Wales 128 Rosemary Collins

8 The Family and Feminism in France Claire Duchen

9 Mary Richmond and the Origins of Social Casework in America Eli Zaretsky

Bibliography

Index 


\section{List of Figures}

6.1 Changes in labour force participation and total fertility 115 rate

6.2 Future potential of care-giving among women 45-59 years 123 per 1000 elderly people

\section{List of Tables}

2.1 Labour force participation rates of sole and married 50 mothers in 1979

5.1 Overcrowding in Italy by type of community and family 102 type, September 1983

5.2 Child-families in Italy according to the number of children 103 aged $0-17$ living in a family, September 1983

5.3 Children aged 0-17 in Italy according to the number of 104 children aged 0-17 living in a family, September 1983

5.4 Families and children aged 0-17 in Italy according to the 105 number of wage earners in the family, September 1983

6.1 Probability of a second child within eight years after first 116 birth for (1) all workers and (2) for workers with uninterrupted employment by age at first birth and level of education

7.1 Affiliation orders as a proportion of father's earnings 


\section{Notes on the Contributors}

Michael Bittman lectures in the School of Sociology at the University of New South Wales. He is co-author (with S. O. D'Alton) of The Social Experience (Melbourne: Nelson, 1974); and he has written articles on time-use in families with infant children, as well as on aspects of the sociology of Max Weber. He is conducting research on intra-family communication and its relation to structural change in the family.

Lois Bryson is an Associate Professor in the School of Sociology at the University of New South Wales. She is co-author (with F. Thompson) of An Australian Newtown: Life and Leadership in a Class Suburb (Ringwood: Penguin, 1972); and she is widely published in the areas of the welfare state, public administration, gender and the family.

Paul Close is a Senior Lecturer in Sociology in the Department of Administrative and Social Studies at Teesside Polytechnic. He is the co-editor (with Rosemary Collins) of Family and Economy in Modern Society (London:Macmillan, 1985); and he has publications in the areas of gender, domestic labour and the links between family life and economic life. He is conducting research on the family and the economy in comparative perspective and on the concept and process of parenting.

Rosemary Collins teaches Sociology at Trent Polytechnic. She is coeditor (with Paul Close) of Family and Economy in Modern Society (London: Macmillan, 1985); and she has publications in the areas of gender and domestic labour. She is involved in a research project on illegitimacy and the law.

Claire Duchen lectures in French at Oxford Polytechnic and teaches Women's Studies in adult education. She is the author of Feminism in France from May '68 to Mitterrand (London: Routledge \& Kegan Paul, 1986) and of Feminism in France: Voices from the Women's Movement in France (London: Hutchison, 1987). 
Joy Hendry lectures in Social Anthropology and Contemporary Japanese Society at Oxford Polytechnic. She has spent several years living and working in Japan. Her various publications in the area of the study of Japanese society include Marriage in Changing Japan (London: Croom Helm, 1981), Becoming Japanese (Manchester University Press, 1986) and Understanding Japanese Society (London: Croom Helm, 1987).

An-Magritt Jensen is a Senior Researcher with the Norwegian Institute for Urban and Regional Research in Oslo, where she is coordinating a research project on the daily life of women and children. She is especially interested in the study of female employment and childbearing; and she is widely published in the areas of demography, childhood, women and work, gender inequality, and women and crime.

Rosemarie Nave-Herz is Professor of Sociology at the University of Oldenburg and the Director of the Research Institute at the University of Hanover. She is widely published in the areas of the family, marriage and demography; and she has recently edited Wandel und Kontinuitat der Familie in der Bundesrepublik Deutschland (Stuttgart: Enke Verlag, 1987).

Angelo Saporiti is a Researcher in the Faculty of Statistics at the University of Rome. His main areas of research cover childhood, family life, social policy and social science methodology. His recent publications are on the topics of one-parent families, fertility decline and evaluation research.

Giovanni Sgritta is Associate Professor of Sociology in the Department of Demographic Sciences at the University of Rome. His research interests and recent publications are in the areas of childhood, family life, social policy and the social services.

Eli Zaretsky is Associate Professor of History at the University of Missouri-Columbia. $\mathrm{He}$ is widely published in the area of the development of modern family life and the welfare state. He is the author of Capitalism, the Family and Personal Life (London: Pluto Press, 1976; revised edition, 1986). His research, under the title of 'liberalism and dependence' is on the roots of the welfare state. 


\section{Acknowledgements}

The editor wishes to express his thanks for the help given by Lesley Holmes, Linda Driver, Margaret Teremetz and Graeme Land in the preparation of this book. He also wishes to express his gratitude to

Derek Allcorn for providing much appreciated guidance over the years. 